\title{
Incidence and Mycotoxigenic Fungi Associated with Cattle Feeds in North Telangana Region, India
}

\author{
A. Bhagya ${ }^{1 *}$, S. Rehana Begum ${ }^{1}$, S. Kiran ${ }^{2}$ and M. Surekha ${ }^{1}$ \\ ${ }^{1}$ Department of Botany, Kakatiya University, Warangal, T.S., India \\ ${ }^{2}$ Department of Botany, Satavahana University, Karimnagar, T.S., India \\ *Corresponding author
}

Keywords

Mycoflora, Cattle feeds, Aspergillus, Penicillium,

Fusarium,

Mycotoxins and Mycotoxigenic fungi

Article Info

Accepted:

17 March 2019

Available Online:

10 April 2019
A B S T R A C T

Mycoflora and mycotoxins contamination of different cattle feed samples of north Telangana region was analysed both quantitatively and qualitatively. The feed samples were highly infested by A. flavus, A. terreus and Penicillium species. The incidence of the rest of the fungi varied with the type of sample and the place of collection. The toxigenic potential of different mycotoxigenic fungi varied with substratum. The strains of A. flavus, A. terreus and Penicillium citrinum elaborated aflatoxin, patulin, terreic acid and citrinin respectively. The significance of occurrence of mycotoxigenic fungi in different fungi in different cattle feed is discussed.

\section{Introduction}

Microscopic fungi and their metabolites of mycotoxins are often found as contaminants in agricultural products before or after harvest as well as during transportation or storage. Animal feeds are routinely subject to contamination from diverse sources, including environmental pollution and activities of insects and microbes. Feed toxins include compounds of both plant and microbial origin, among microbes, fungal contamination is a concerning issue in animal nutrition products for human. There are consistent reports of worldwide contamination of feeds with fungi and their spores. Aspergillus is the predominant genus in dairy and other feeds (Mohammad et al., 2015) other species include Penicillium, Fusarium and Alternaria, which are also important contaminants of cattle feeds and cereal grains (Alonso et al, 2013 and Surekha et al., 2017) when cereal grains and animal feed are colonised by moulds there is a significant risk of contamination with the secondary metabolites of these fungi (Goncalves et al., 2015). These fungi contaminate wide range of agricultural products mainly cereal gains, during pre and 
post-harvest stage (Khoury et al., 2011). Rafai et al., (2000), Eriksen and Pettersson (2004), Wu et al., (2007), Adamse et al., (2012) and Elisabeth et al., (2012) have discussed various aspects of the incidence of mould infestation and mycotoxin contamination of cattle feed and significant health effects on farm animals. Presence of mycotoxins in feeds may also decrease feed intake and affect animal performance. In addition to possible presence of toxic residues in edible products (milk, meat etc) may have harmful effects on human health. Contamination of cattle feeds and feed ingredients with mycotoxins has been reported from different parts of the world (Reddy et al., 2000; Sultana and Hanif, 2009 and Surekha et al., 2017). In the present investigations detection of fungi in different cattle feeds which are commonly used in feed formulation in the Telangana region which is warm and humid conditions prevail during most part of the year.

\section{Materials and Methods}

Habitual survey of cattle feeds (Green gram, Legume mixture, Mixed Feed and Commercial feed) which generally used as feed ingredients of livestock in the Telangana regions was conducted. The details of the condition of samples, age of samples and place of collection were recorded carefully. The sample was subjected to analysis of mycoflora by dilution plate method (Waksman, 1922). The fungi appeared were isolated, purified and identified with the help of standard manuals (Singh et al., 1999, Mathur and Kongsdal, 2003 and Lislie and Summerel, 2006). The fungal isolated were grown in Czapek's dox medium (Sucrose30g; NaNo3-3.0g; $\mathrm{KH}_{2} \mathrm{PO}_{4}-1 \mathrm{~g} ; \mathrm{KCl}-0.5 \mathrm{~g} ; \mathrm{FeSO}_{4} 7$ $\mathrm{H}_{2} \mathrm{O}-0.01 \mathrm{~g} ; \quad \mathrm{MgSO}_{4} \quad 7 \mathrm{H}_{2} \mathrm{O}-0.5 \mathrm{~g}$; distilled water- $1000 \mathrm{ml}$ ) and assessed for their mycotoxin producing potential. Old culture was harvested and culture filtrate was employed for detection of different mycotoxin Liquid - liquid extraction was employed using appropriate solvent. The extractant was concentrated and subjected to TLC separations. The TLC plates thus developed were observed under long wave UV light (360 $\mathrm{nm})$ and they were further confirmed with help of colour tests and spray reagents.

\section{Results and Discussion}

Sixteen fungal species representing 10 genera were recorded in green gram feed samples (Table 1). Aspergillus flavus, A. niger $A$. nidulans, A. terreus, Fusarium and Penicillium were associated with all the samples collected from different North Telangana Region. While Paecilomyces variotii, Rhizoctonia solani and Syncephalastrum racemosum were associated only with samples collected from Karimnagar, Peddapalli and Asifabad respectively. Drechslera nodulasa, $D$. spicifera, Memnoniella echinata and Rhizopus stolonifer were recorded in samples collected from only a few places. The percentage of incidence of A. flavus was highest in most of the samples.

Aspergillus flavus, A.terreus and Penicillium were with highest percentage of frequency, while Paecilomyces variotii, Rhizoctonia solani and Syncephalastrum racemosum was with lowest percentage of frequency. Percentage of abundance of A. flavus was highest followed by A. terreus and species of Penicillium, Syncephalastrum racemosum and Memnoniella echinata were lowest in their abundance. (Interestingly, thought the incidence and frequency of Syncephalastrum racemosum was low, its abundance was more). In general incidence of A. flavus and A. terreus was more. Similarly specie of Penicillium was also considerably high in their percentage of incidence and can be much significance in the livestock health. 
Eighteen Fungal species respecting six genera were recorded in legume mixture feed samples collected from different north Telangana region. A. flavus, A. niger, Cladosporium herbarum and Penicillium were associated with all the samples, while $A$. ochraceus, Cladosporium herbarum and Paecilomyces variotii was isolated only from samples of Warangal and Peddapalli. A. flavipes, A. nidulans, A. terreus and Syncephalastrum racemosum were recorded in samples of only some places. The incidence of A. flavus was highest followed by $A$. niger species of $C$. lunata and Penicillium in a descending order. A. flavus, A. niger, C. lunata and species of Penicillium were with highest percentage of frequency, while it was least with $A$. ochraceus, Cladosporium herbarum and Paecilomyces variotii. A. flavus followed by species of Fusarium, A. niger, Penicillium and A. terreus were with highest percentage of abundance on the other hand, Paecilomyces variotii and Cladosporium herbarum occurred with lowest percentage of abundance.

Mixed feed samples collected from different region of Telangana supported fifteen fungal species representing six genera. A. flavus, $A$. terreus, Fusarium and Penicillium were recorded in all the samples, while A. nidulans and Drechslera nodulasa were associated only with samples collected Adilabad, Asifabad, Peddapalli and Jagityal respectively. Alternaria alternate, A. flavipes, A. ochraceus and Rhizopus stolonifer were recorded in samples of only some places. The incidence of $A$. flavus followed by species of Fusarium and Penicillium was highest in all the samples collected. A terreus was next dominant fungus. The highest incidence of $A$. flavus may pose health hazard to livestock and in turn to man. A flavus was highest in percentage of frequency and abundance followed by $A$. terreus and species of Fusarium and Penicillium in a descending order, while it was least with Alternaria alternate.

Fifteen fungal species representing 5 genera were recorded in commercial feed collected from different north Telangana region. A. flavus A. niger and species of Fusarium and Penicillium were associated with almost all the samples collected from different places of Telangana. A. ochraceus was isolated only from samples of Bhupalpally respectively. $A$. flavipes, A. nidulans, A. terreus species of Cladosporium and Trichoderma were recorded in samples of only some places. The percentage of frequency and abundance of $A$. flavus followed by species of Fusarium, Penicillium and A. niger was high, while $A$. ochraceus and A. flavipes were least.

From the present investigations it is clear that cattle feeds are ideals substrates for mould infestation commercial feed being highly preferred, while green gram feed is least preferred, substratum for A. flavus infestation legume mixture and mixed feeds are preferred substrates for the growth of Penicillium species, commercial and mixed feed was the best substrate for the growth of Fusarium species. The incidence of other fungi in different cattle feed samples was not only inconsistent but also sporadic.

The toxigenic potential of different fungi varied with the substratum (Table 2). Among the fungi associated with green gram feed only A. flavus A. terreus and Penicillium citrinum were able to elaborate aflatoxins, patulin, terreic acid and citrinin, respectively.

About $68 \%$ of A. flavus isolated were positive for aflatoxins production, while $66 \%$ of isolates of $P$. citrinum were positive for citrinin production. None of the isolates of $P$. griseofulvum and $A$. nidulans were capable of producing cyclopiazonic acid (CPA) and sterigmatocystin, respectively. 
Int.J.Curr.Microbiol.App.Sci (2019) 8(4): 2247-2253

Table.1 Mycoflora of cattle feeds

\begin{tabular}{|c|c|c|c|c|c|c|c|c|c|c|c|}
\hline \multirow{2}{*}{$\begin{array}{l}\text { Name of } \\
\text { the fungus }\end{array}$} & \multicolumn{9}{|c|}{ Percentage of Incidence } & \multirow[b]{2}{*}{$\begin{array}{l}\text { Percentage } \\
\quad \text { of } \\
\text { Frequency }\end{array}$} & \multirow[b]{2}{*}{$\begin{array}{l}\text { Percentage of } \\
\text { abundance }\end{array}$} \\
\hline & $\mathbf{A}$ & B & $\mathbf{C}$ & D & $\mathbf{E}$ & $\mathbf{F}$ & $\mathbf{G}$ & $\mathbf{H}$ & I & & \\
\hline \multicolumn{12}{|l|}{ Green gram feed } \\
\hline Alternaria alternate & 0.80 & 0.60 & - & 8.00 & 2.60 & 1.80 & $\mathrm{~N}$ & $\mathrm{~N}$ & $\mathrm{~N}$ & 83.30 & 10.50 \\
\hline A. flavus & 38.20 & 30.30 & 38.60 & 20.30 & 35.20 & 21.30 & $\mathrm{~N}$ & $\mathrm{~N}$ & $\mathrm{~N}$ & 100.00 & 28.40 \\
\hline A. nidulans & 3.80 & 4.20 & 6.30 & - & - & 8.70 & $\mathrm{~N}$ & $\mathrm{~N}$ & $\mathrm{~N}$ & 66.60 & 6.30 \\
\hline A. niger & 12.40 & 2.10 & 10.40 & 28.60 & 11.30 & - & $\mathrm{N}$ & $\mathrm{N}$ & $\mathrm{N}$ & 83.30 & 9.60 \\
\hline A. terreus & 20.30 & 28.20 & 25.80 & 36.20 & 38.30 & 32.20 & $\mathrm{~N}$ & $\mathrm{~N}$ & $\mathrm{~N}$ & 100.00 & 25.80 \\
\hline Curvularia lunata & 2.30 & 2.80 & - & - & 3.60 & 4.40 & $\mathrm{~N}$ & $\mathrm{~N}$ & $\mathrm{~N}$ & 66.60 & 8.80 \\
\hline Drechslera nodulasa & - & - & 2.40 & - & 4.80 & - & $\mathrm{N}$ & $\mathrm{N}$ & $\mathrm{N}$ & 33.30 & 6.50 \\
\hline D. spicifera & - & - & - & 2.00 & - & 2.80 & $\mathrm{~N}$ & $\mathrm{~N}$ & $\mathrm{~N}$ & 33.30 & 1.80 \\
\hline Memnoniella echinata & - & 2.20 & - & 0.80 & - & - & $\mathrm{N}$ & $\mathrm{N}$ & $\mathrm{N}$ & 33.30 & 0.60 \\
\hline Paecilomyces variotii & 1.80 & - & - & - & - & - & $\mathrm{N}$ & $\mathrm{N}$ & $\mathrm{N}$ & 16.60 & 3.60 \\
\hline $\begin{array}{l}\text { Penicillium spp }(P . \\
\text { citrinum, } P . \text { viridicatum, } \\
P . \text { islandicum })\end{array}$ & 16.30 & 12.20 & 11.80 & 3.20 & 2.50 & 15.80 & $\mathrm{~N}$ & $\mathrm{~N}$ & $\mathrm{~N}$ & 100.00 & 18.30 \\
\hline Rhizopus stolonifer & 5.10 & 17.20 & - & - & - & 18.00 & $\mathrm{~N}$ & $\mathrm{~N}$ & $\mathrm{~N}$ & 66.60 & 14.30 \\
\hline Rhizoctonia solani & - & - & - & 1.70 & - & - & $\mathrm{N}$ & $\mathrm{N}$ & $\mathrm{N}$ & 16.60 & 0.80 \\
\hline $\begin{array}{l}\text { Syncephalastrum } \\
\text { racemosum }\end{array}$ & - & - & - & - & 1.70 & - & $\mathrm{N}$ & $\mathrm{N}$ & $\mathrm{N}$ & 16.60 & 0.40 \\
\hline \multicolumn{12}{|l|}{ Legume mixture feed } \\
\hline Aspergillus flavipes & - & 3.60 & - & 6.30 & $\mathrm{~N}$ & 4.10 & $\mathrm{~N}$ & $\mathrm{~N}$ & $\mathrm{~N}$ & 60.00 & 8.30 \\
\hline A. flavus & 36.50 & 20.30 & 28.20 & 30.60 & $\mathrm{~N}$ & 38.60 & $\mathrm{~N}$ & $\mathrm{~N}$ & $\mathrm{~N}$ & 100.00 & 25.60 \\
\hline A. nidulans & - & 3.80 & 2.50 & 1.60 & $\mathrm{~N}$ & - & $\mathrm{N}$ & $\mathrm{N}$ & $\mathrm{N}$ & 60.00 & 11.30 \\
\hline A. niger & 10.30 & 15.30 & 12.50 & 10.30 & $\mathrm{~N}$ & 10.20 & $\mathrm{~N}$ & $\mathrm{~N}$ & $\mathrm{~N}$ & 100.00 & 20.30 \\
\hline A. ochraceus & - & 1.20 & - & - & $\mathrm{N}$ & - & $\mathrm{N}$ & $\mathrm{N}$ & $\mathrm{N}$ & 20.00 & 6.50 \\
\hline A. terreus & 6.20 & - & 8.30 & 12.20 & $\mathrm{~N}$ & 4.10 & $\mathrm{~N}$ & $\mathrm{~N}$ & $\mathrm{~N}$ & 80.00 & 15.30 \\
\hline Cladosporium herbarum & - & 0.20 & - & - & $\mathrm{N}$ & - & $\mathrm{N}$ & $\mathrm{N}$ & $\mathrm{N}$ & 20.00 & 0.80 \\
\hline C. lunata & 6.30 & 1.10 & 4.50 & 4.00 & $\mathrm{~N}$ & 6.80 & $\mathrm{~N}$ & $\mathrm{~N}$ & $\mathrm{~N}$ & 100.00 & 2.90 \\
\hline $\begin{array}{l}\text { Fusarium spp. }(F . \\
\text { moniliforme, } \\
\text { F.oxysporum, } F \text { solani, } F \text {. } \\
\text { equiseti) }\end{array}$ & 21.20 & 18.50 & 19.50 & - & $\mathrm{N}$ & 18.20 & $\mathrm{~N}$ & $\mathrm{~N}$ & $\mathrm{~N}$ & 80.00 & 23.60 \\
\hline Paecilomyces variotii & - & - & - & 1.30 & $\mathrm{~N}$ & - & $\mathrm{N}$ & $\mathrm{N}$ & $\mathrm{N}$ & 20.00 & 0.30 \\
\hline $\begin{array}{l}\text { Penicillium spp. (P. } \\
\text { citrinum, } P \text {. viridicatum, } \\
P . \text { funiculosum, } P . \\
\text { griseofulvum, }\end{array}$ & 18.50 & 26.80 & 24.20 & 28.30 & $\mathrm{~N}$ & 11.20 & $\mathrm{~N}$ & $\mathrm{~N}$ & $\mathrm{~N}$ & 100.00 & 18.60 \\
\hline $\begin{array}{l}\text { Syncephalastrum } \\
\text { racemosum }\end{array}$ & 1.20 & 3.50 & - & - & $\mathrm{N}$ & 1.80 & $\mathrm{~N}$ & $\mathrm{~N}$ & $\mathrm{~N}$ & 60.00 & 1.40 \\
\hline \multicolumn{12}{|l|}{ Mixed Feed } \\
\hline Alternaria alternate & - & - & 1.20 & - & 4.00 & 0.80 & - & - & $\mathrm{N}$ & 37.50 & 0.80 \\
\hline Aspergillus flavipes & - & 8.80 & - & 1.60 & - & - & 3.40 & - & $\mathrm{N}$ & 37.50 & 1.80 \\
\hline A. flavus & 28.30 & 26.30 & 28.80 & 35.60 & 25.00 & 24.00 & 25.80 & 22.50 & $\mathrm{~N}$ & 100.00 & 33.30 \\
\hline A. nidulans & - & - & 13.20 & - & 7.80 & - & - & - & $\mathrm{N}$ & 25.00 & 1.80 \\
\hline A. ochraceus & 10.00 & - & - & 1.20 & - & - & 8.50 & 13.60 & $\mathrm{~N}$ & 50.00 & 3.60 \\
\hline A.terreus & 13.50 & 22.80 & 12.20 & 15.60 & 15.80 & 16.00 & 14.20 & 17.50 & $\mathrm{~N}$ & 100.00 & 11.30 \\
\hline Drechslera nodulasa & - & - & - & 5.60 & - & 6.20 & - & - & $\mathrm{N}$ & 25.00 & 1.20 \\
\hline
\end{tabular}




\begin{tabular}{|c|c|c|c|c|c|c|c|c|c|c|c|}
\hline $\begin{array}{l}\text { Fusarium spp. }(F . \\
\text { moniliforme, } F \text {. } \\
\text { Oxysporum, } F \text { solani, } F \text {. } \\
\text { equiseti) }\end{array}$ & 10.30 & 12.50 & 15.60 & 22.40 & 26.30 & 24.40 & 18.60 & 12.30 & $\mathrm{~N}$ & 100.00 & 26.50 \\
\hline $\begin{array}{l}\text { Penicillium spp. (P. } \\
\text { citrinum, } P . \text { viridicatum, } \\
P . \text { griseofulvum, })\end{array}$ & 3.30 & 29.60 & 28.00 & 13.60 & 21.10 & 24.80 & 20.80 & 25.10 & $\mathrm{~N}$ & 100.00 & 20.30 \\
\hline Rhizopus stolonifer & 7.70 & - & - & 4.40 & - & 3.80 & 10.50 & 9.00 & $\mathrm{~N}$ & 62.50 & 6.50 \\
\hline \multicolumn{12}{|l|}{ Commercial feed } \\
\hline Aspergillus flavipes & 2.60 & - & - & 8.30 & - & - & 2.80 & - & - & 33.30 & 0.80 \\
\hline A. flavus & 20.30 & 25.80 & 26.80 & 10.80 & 35.60 & 25.80 & 32.50 & 20.20 & 14.80 & 100.00 & 38.60 \\
\hline A. nidulans & - & 3.20 & 1.80 & - & 1.60 & 2.50 & - & 3.80 & 18.20 & 66.66 & 11.30 \\
\hline A. niger & 11.30 & 12.80 & 13.30 & 10.80 & 6.30 & 11.60 & 3.80 & 18.60 & 12.80 & 100.00 & 10.30 \\
\hline A. ochraceus & - & - & - & - & - & - & - & 1.20 & - & 11.10 & 0.20 \\
\hline A.terreus & - & - & 1.20 & - & 2.50 & - & 8.80 & - & - & 33.30 & 1.50 \\
\hline Cladosporium herbarum & 1.60 & - & 2.30 & - & - & 10.90 & - & - & 4.60 & 44.40 & 2.70 \\
\hline $\begin{array}{l}\text { Fusarium spp. }(F . \\
\text { moniliforme, } F \text {. } \\
\text { oxysporum, } F \text { solani, })\end{array}$ & 26.40 & 28.20 & 15.80 & 25.60 & 23.00 & 25.00 & 24.50 & 22.90 & 26.60 & 100.00 & 30.30 \\
\hline $\begin{array}{l}\text { Penicillium spp. (P. } \\
\text { citrinum, } P \text {. oxalicum, } P \text {. } \\
\text { griseofulvum, })\end{array}$ & 28.20 & 16.40 & 32.50 & 32.60 & 20.60 & 15.00 & 21.30 & 25.00 & 28.00 & 100.00 & 18.30 \\
\hline Trichoderma viride & 1.80 & - & - & 3.40 & - & - & 3.50 & - & 3.60 & 44.40 & 8.20 \\
\hline
\end{tabular}

$\mathrm{A}=$ Karimnagar, $\mathrm{B}=$ Warangal, $\mathrm{C}=$ Adilabad, $\mathrm{D}=$ Peddapalli, $\mathrm{E}=$ Asifabad, $\mathrm{F}=\mathrm{Jagityal}, \mathrm{G}=\mathrm{Nirmal}, \mathrm{H}=\mathrm{Bhupalpally}, \mathrm{I}=$ Mancherial

Table.2 Toxigenic potential of fungi of cattle feeds

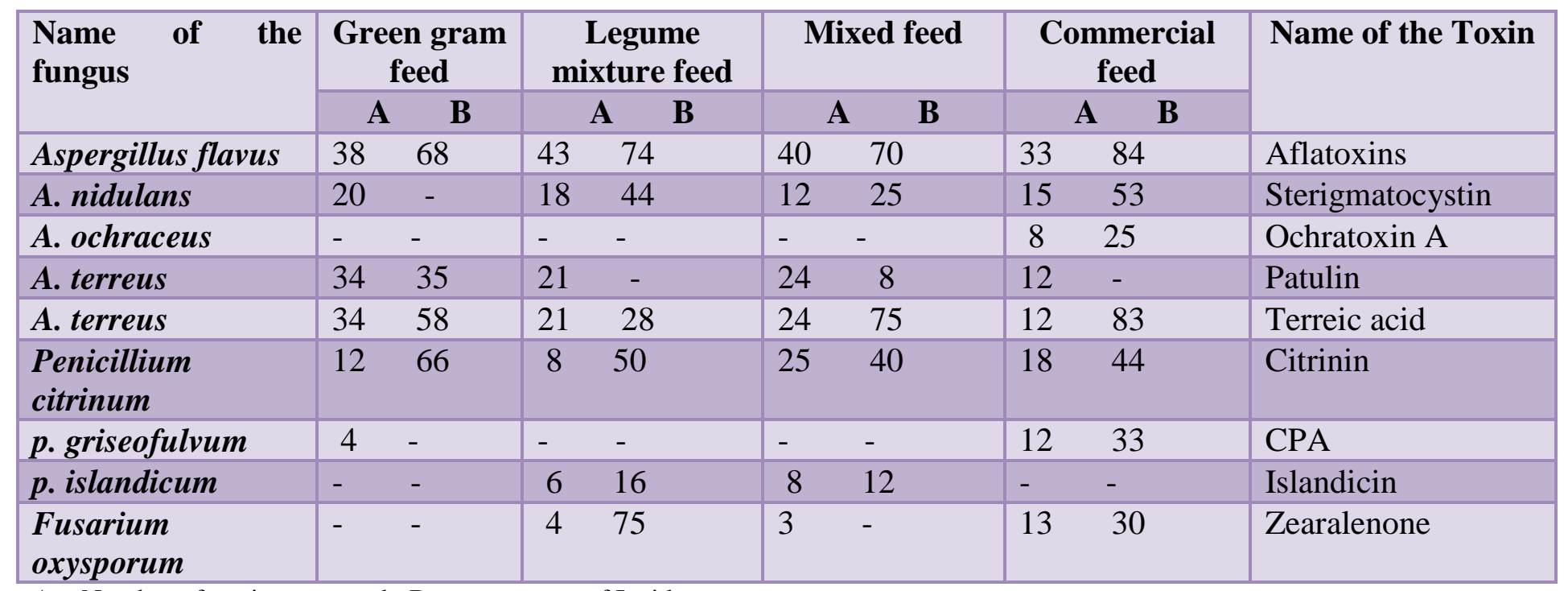

$\mathrm{A}=$ Number of strains screened, $\mathrm{B}=$ percentage of Incidence

The fungi associated with legume mixture were potential of elaborating mycotoxins. However, the percentage of toxigenic isolates varied. None the isolates of $A$. terreus could elaborate patulin out of 4 isolates of $F$. oxysporum, 3 were positive for zearalenone production one isolate out of 6 strains of $P$. islandicum, screened elaborated islandicin. Interestingly mixed feeds and commercial feeds proved to be more susceptible to mould infestation and supported elaboration of various mycotoxins that about $70 \%, 25 \%$ and 
$40 \%$ of isolates of A. flavus, A. nidulans and $P$. citrinum respectively of mixed feeds were toxigenic. Two out 3 isolates of $F$. oxysporum screened elaborated zearalenone. Isolates of $P$. islandicum (12\%) elaborated islandicin respectively. Similarly commercial feeds were also ideal substrates for toxigenic moulds. About $84 \%$ of $A$. flavus isolates were positive for aflatoxins production, while $53 \%$ and $25 \%$ of isolates of A. nidulans and A. ochraceus respectively were able to elaborate sterigmatocystin and ochratoxin $A$ respectively. None of the isolates of $A$. terreus could elaborate patulin, while $83 \%$ of $A$. terreus strains elaborated terreic acid, when $P$. citrinum and $P$. griseofulvum strains were screened. $44 \%$ and $33 \%$ of strains were positive for citrinin and CPA respectively.

\section{Acknowledgment}

Thanks are due to the Head, Department of Botany, Kakatiya University and for providing laboratory facilities and RGNF University Grant Commission New Delhi for Financial Assistance.

\section{References}

Adamse, P, van Egmond HJ, Driessen JJM, de Rijk T.C, de Jong J, de Nijs M. Trend. 2012. Analysis of Mycotoxins in Animal Feed. RIKILT-Institute of Food Safety; Wageningen, the Netherlands: pp. 1-52.

Alonso, A.V., C.M. pereyr, L.A.M. Keller, A.M. Dalcero, C.A.R. Rosa, S.M. Chiacchiera and L.R. Cavaglieri, 2013. Fungi and Mycotoxins in silage: An overview J. Applied microbial, 115: 637-643.

Goncalves, B.L., C.H. Corassin and C.A.F. Oliveira, 2015. Mycotoxicoses in Dairy Cattle: A Review. Asian Journal of Animal and Veterinary Advances, 10: 752-760.
Elisabeth, S, G. Schatzmayr, P. Tassis, E. Tzika, D. Marin, I. Taranu, C. Tabuc, A. Nicolau, I. Aprodu, O. Puel and I P. Oswald. 2012. Current Situation of Mycotoxin Contamination and Co-occurrence in Animal FeedFocus on Europe. Toxins (Basel). 4(10): 788-809.

Eriksen, G.S., Pettersson H. 2004. Toxicological evaluation of trichothecenes in animal feed. Anim. Feed Sci. Technol. ;114:205-239.

Kangethe, EK., and Langa KA. 2009. Aflatoxin B1 and M1 contamination of animal feeds and milk from urban centers in Kenya. Afr Health Sci. 9 (4):218-26.

Lislie JE and Summerel BA. 2006. The Fusarium Laboratory manual. 1st ed., Blackwell Publishing Professional, USA, 247 pp. 8.

Mathur, SB., and Kondgsdal O. 2003. Common laboratory seed health testing methods for detecting fungi. International Seed Testing Association, Switzerland. 234-255.

Mohammad, R., IM Pourfard, M Yahyaei , M Gholamrezaei , R. Ghasemikhah and M. Kazemi-Bonchenari. 2015. Evaluation of some dairy and beef cattle feed samples for fungal contamination in Markazi Province of Iran. Int.J.Curr.Microbiol.App.Sci. 4(6): 1139-1146.

Rafai, P., Bata Á., Jakab L., Ványi A. 2000. Evaluation of mycotoxincontaminated cereals for their use in animal feeds in Hungary. Food Addit. Contam. 17:799-808.

Reddy, DVK, Thirumala Devi K, Reddy SV, Waliyar F, Mayo MA, Rama Devi K, Ortiz R and Lenne JM. 2000. Estimation of Aflatoxin Levels in Selected Foods and Feeds in India. Proceedings of the International Workshop, Montpellier, France, 11- 
13.

Singh, K., Frisrad JC, Thrane U and Mathur SB. 1999. An illustrated manual on identification of some-borne Aspergilli, Fusaria, Penicillia and their mycotoxins. Danish Govt. Institute of Seed Pathology for Developing Countries. Denmark. 1999; 6-122.

Sultana, N., and Hanif NQ. 2009. Mycotoxin contamination in cattle feed and feed ingredients. Pak Vet J, 29: 211-213.

Surekha, M.S., Kiran, M. Naga Raju and S.M. Reddy. 2017. Incidence of mycotoxigenic fungi in livestock animal Feed cakes of Godavari belt regions of Andhra Pradesh (India). Indian Journal of applied Research. 7: 471-474.

Waksman, SA., 1922. A method of counting the number of fungi in soil. $J$. Bacteriol. 7: 339-341.

$\mathrm{Wu}$, F. 2007. Measuring the economic impacts of Fusarium toxins in animal feeds. Anim. Feed Sci. Technol. 137: 363-374.

\section{How to cite this article:}

Bhagya, A., S. Rehana Begum, S. Kiran and Surekha, M. 2019. Incidence and Mycotoxigenic Fungi Associated with Cattle Feeds in North Telangana Region, India. Int.J.Curr.Microbiol.App.Sci. 8(04): 2247-2253. doi: https://doi.org/10.20546/ijcmas.2019.804.262 